\title{
What Causes Poverty?: A Postmodern View
}

\author{
Lakshman Yapa
}

Department of Geography, Pennsylvania State University

$\mathbf{P}$ eople are considered poor when they are unable to satisfy their basic needs for food, clothing, shelter, and health. Using minimum costs of food and other necessities as poverty criteria, the World Bank estimated in 1988 that 1,133 million, or 29.7 percent of the total population in developing countries, were poor (World Bank 1992:30). According to the same estimate 49 percent in South Asia and 47.8 percent in sub-Saharan Africa were poor. It is widely believed that such poverty reflects economic underdevelopment of nations whose poorly developed production forces such as land, capital, and labor have hampered economic growth; naturally, economic development is viewed as the obvious solution. By this logic, investments in development projects, infrastructure, modernized agriculture, and expanded exports would alleviate poverty by creating jobs and providing income. We call this the axiom of economic development.

The principal hypothesis of the paper is the following: the material deprivation experienced by the poor is a form of socially constructed scarcity. Poverty does not reside exclusively in the external world independent of academic discourse that thinks about it; discourse is deeply implicated in creating poverty insofar as it conceals the social origins of scarcity. Although the experience of hunger and malnutrition is immediately material, "poverty" exists in a discursive materialist formation where ideas, matter, discourse, and power are intertwined in ways that virtually defy dissection. To study such formations, we must first transcend the limits, assumptions, and language of social science. I contend that a postmodern discursive approach yields a more satisfactory view of the poverty problem: 1 ) it reveals a multiplicity of causative relations; 2) it points the way to multiple possibilities of action; 3 ) it moves beyond the realm of poverty experts to identify numerous agents of social change; and 4) it yields a new understanding of the power we possess to act in the world.

The paper is organized into four parts. In the first part I try to establish a link between postmodern discourse theory and the theoretical framework of the nexus of production relations. Next I describe the concept of socially constructed scarcity, an idea that underlies my entire argument. In the third section I adapt two Foucaldian notions of power-"disciplinary" power and "nonsovereign" power-to think about nontraditional "solutions" to poverty. Finally, I use this postmodern view of poverty to locate my own work as author.

\section{Discourse Theory and Poverty}

\section{Postmodernism}

Postmodernism as Object and Attitude. The idea of postmodernism can be understood in two related but distinct ways: as object and as attitude (Cloke, Philo, and Sadler 1991:170201). As object, postmodernism is about ontology-a description of our world. It claims that "the modern world" has changed qualitatively in the last 25 years. The center has given way to a fragmented world of politics of difference: voices from the margin, pastiche in art and architecture, post-Fordist capital accumulation, rapid information technology, bewildering variety in the marketplace, and accelerated consumption (Young 1990; Lyotard 1979; Harvey 1989; Xenos 1989; Poster 1990). ${ }^{1}$ As attitude, postmodernism is a theoretical and representational mood (Waugh 1992)-a mood of skepticism with modern certainties. As attitude, postmodernism is about epistemologyhow we know what we know. It questions the nature of reason, objectivity, truth, representation, and humanism. It questions the au- 
thority of social science to diagnose social ills and recommend policy (Roseneau 1992). It is this latter sense of postmodernism that is the concern here. Important and interesting as they are, I do not pursue ontological questions of the postmodern condition in this paper. ${ }^{2}$

Some may argue that the distinction between postmodernism as object (ontology) and attitude (epistemology) is false because the postmodern mood is a reflection of underlying material changes in society. This is certainly the view of Jameson (1984), who sees postmodernism as the cultural logic of late capitalism. For Harvey (1989), too, postmodernity is a cultural condition reflecting the new economic logic of flexible accumulation and the disorienting sense of accelerated compression of space and time. Without contesting the validity of these theses, I contend that postmodern attitudes raise important questions about the nature of signs, representation, language, power, and policy. Their relevance does not depend on the empirical status of postmodernity as condition.

Postmodernism as epistemology argues that social science cannot serve as "a mirror of society." Knowledge arises out of embodiment in society; it always has and always will. ${ }^{3}$ Social science and society bear a codependent and necessary symbiotic relationship to each other. The relation of society to social science occurs as both object and subject-a central issue whose implications have not been sufficiently recognized by social scientists. According to Foucault (1973b), "Man" provides not only the object of social science but also the conditions under which that knowledge is acquired. Cousins and Hussain (1984:50), commenting on Foucault's thoughts, observe that "this tension cannot be said to be one which can be resolved. No conceptual advance, no empirical finding within the social sciences, can resolve it. The tension is constitutive of the human sciences as such." My comment is not to say that social science is inferior to natural science in this; it is to say that social science is not, was not, nor need be "value-free" in order to be useful knowledge.

Postmodernizing Social Science. Postmodern contentions can help us make explicit the codependent relationship between social science and society. For now I shall describe this as the postmodernizing of social science. We can implement this project: 1) by pointing out the constructivist nature of social processes (Lyotard 1979); 2) by insisting that social science's epistemology be more reflexive on how it knows (Aronowitz 1988; Proctor 1991); 3) by admitting that "data" do not exist independent of our social theory (Sayer 1992; Gregory 1978); 4) by recognizing language's important role in cognition (Derrida 1978; Sarup 1988:6-62); 5) by working within the bounds defined by semiotics which denies an unambiguous correspondence between a sign and what it signifies (Gottdiener 1994); 6) by tracing the history of disciplines such as sociology, economics, and geography to show that basic categories such as deviancy, social mobility, resources, scarcity, and region do not carry universal meanings valid for all cultures and social groups (Foucault 1973a; Livingstone 1992; Smith and Godlewska 1994; Merchant 1983; Sachs 1992); and 7) by acknowledging that power is deeply implicated in the production and use of social-science knowledge (Proctor 1995; Rouse 1987; Foucault 1980). ${ }^{4}$ But this said, why is the postmodernizing of social science (and society) relevant for Third World poverty? It is my contention that academic understandings of poverty and their representations in our textbooks and policy reports lie at the heart of the story. Discourse theory can help us understand why poverty cannot be alleviated within the epistemology of conventional social science.

Skeptics and Affirmatives. Reading postmodern writers such as Lyotard, Derrida, Foucault, and Baudrillard is difficult. The writing is technical, dense, and opaque, and their conclusions are often divergent and even contradictory. According to Roseneau (1992:15), "within this diversity of post-modern pronouncements, as far as the social sciences are concerned, two broad, general orientations, the skeptical post-modernists and the affirmative post-modernists, can be delineated." The skeptical postmodernists offer a gloomy, negative assessment of the contemporary world as one of fragmentation, malaise, and meaninglessness; hence, no political project is worthy of commitment. Roseneau (1992:15) believes that the skeptics are inspired by Continental European philosophers, especially Nietzsche; they practice a form of politics of despair; they speak of the death of the subject and author, 
the impossibility of knowing truth, and the abolition of social science. The affirmative postmodernists share this sense of disenchantment with modernity and the failed promises of the Enlightenment. Yet, they retain a more hopeful, optimistic view of postmodernism's possibilities. They are open to, and participate in, issue-specific social movements; they eschew the relativist stance of "anything goes"; they take ethical stands and make normative choices. Roseneau's (1992) distinction suggests that much of the hostility shown toward postmodern theorizing has arisen from a failure to appreciate the distinction between the affirmatives and the skeptics.

\section{The Nexus of Production Relations}

The analytical scheme used here is "the nexus of production relations" (Yapa 1996; Yapa and Wisner 1995). Production is an economic activity only in the narrowest sense of the word because it includes far more than technology, goods, and markets. Production is conducted within a network of discursive and nondiscursive relations-technical, social, ecological, cultural, political, and academic-whose understanding is distorted by subject-specific views of reductionist science (Figure 1). I have borrowed the term "production relations" from Marx (1989 [1869]). In doing so, I have extended the term's meaning beyond the "social," its original usage. I have consciously tried to avoid the problems of the Marxian scheme of associating social relations with the economic base, and matters of culture, knowledge, and ideology with the superstructure; I explore the interactions among these relations without regard for those that may be more determinate or "essential. ${ }^{\text {" }}$ These relations should not be conceived of as discrete analytical categories; depending on the purpose at hand, any node may be subdivided or a new one added. These relations act and react upon each other constantly to maintain a dynamic system of mutually constituted elements. An entity that appears to be technological from one angle or at one time may be thought of as academic or social from another angle or time,

\section{The nexus of production relations of poverty}

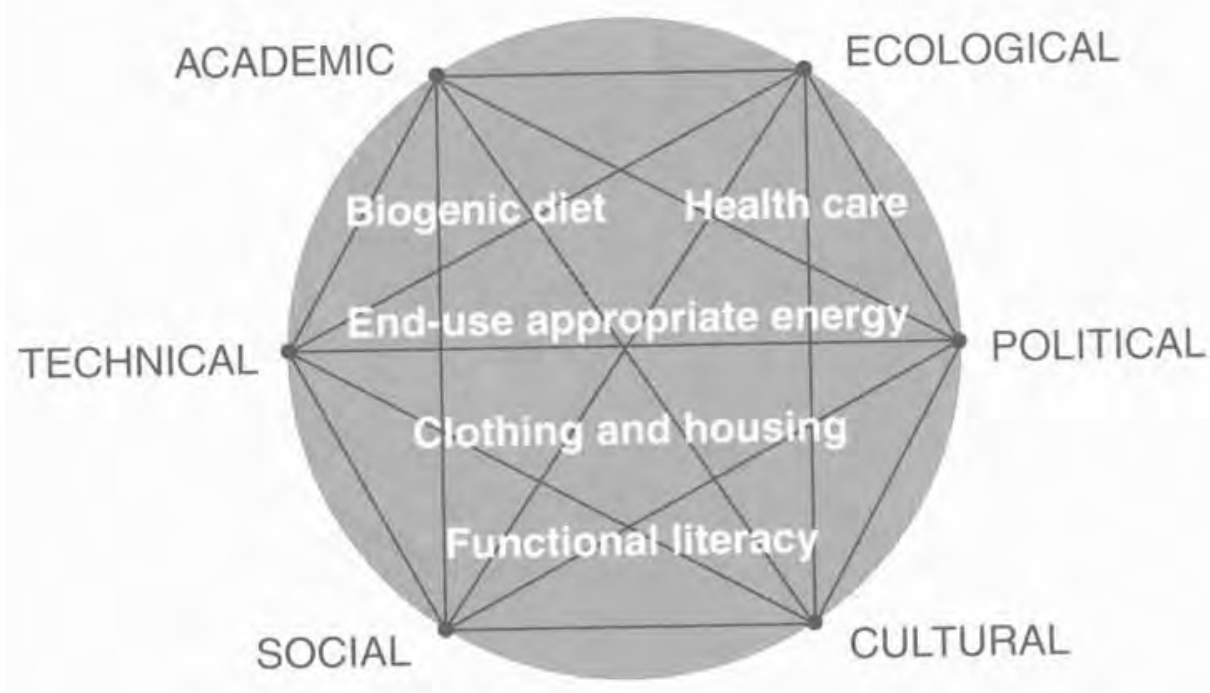

Figure 1. The nexus of production relations of poverty. 
or what appears to be academic may be better treated with language that is social or cultural, and so on. The diagram of the nexus should not be misconstrued. All nodes are not equally important for a given outcome, but the relative ranking of relations is a matter to be decided on a case-by-case basis.

In any event, the nexus of production shown in Figure 1 is not a model of economic reality; it is a discursive device constructed to enable a conversation about poverty. The phrase "technical relations of production" refers to a concept similar to Marx's forces of production, in which he included raw materials, resources, labor, and technology used in production (Marx 1989 [1869]). I prefer the term "technical relations" to call attention to the fact that attributes of production forces are determined in a larger context (i.e., by other relations) in which production occurs. The term "social relations of production" is used in a manner identical to its use in Marxian economics, where it refers to ownership of the means of production, the manner in which the means of production are utilized, and the rules for the social distribution of the final product (Marx 1989 [1869]). Production requires matter and energy as inputs and a repository to hold waste materials, chemicals, and heat, setting in motion a myriad of interactions with the biophysical environment-"the ecological relations of production." The phrase "cultural relations of production" refers to the interaction of production with "the ways of life" of social groups as embodied in shared meaning, beliefs, values, symbols, signs, and language. "Political relations of production" include interactions between the state and society in the organization of economic activity. The state plays a key role in resource allocation in both centrally planned and market economies. In Third World economies the state has come to play an all-pervasive role in civil society through its command over the development project. The concept of "academic relations of production" is central to a postmodern view of poverty. Academic relations are of two kinds: internal and external. Internal relations arise from the understanding science has of itself in the production of knowledge. Mainstream social science claims that its work is neutral, value-free, and nonpolitical (Proctor 1991), and that its norms and standards are self-evident (Aronowitz 1988). The postmodern critique of social science arises largely from science's image of itself. External academic relations refer to the discourses that are produced at other sites in the nexus: technical, social, cultural, political, and ecological-where our understanding of technology, property, culture, the state, and nature is mediated through social theories produced about these matters (Demeritt 1994). Thus each node of the nexus is the site of both discursive and nondiscursive practices.

Language and discourse make us conscious of material processes (practice), but the form of that understanding (how we know) is influenced by both material processes and choice of language. The relation between discourse and material is not confined to the intellectual task of providing an understanding of material; by acting on our understanding, discourse affects practice (the material). Moreover, discourse is not conducted under rules of free inquiry; it is constructed out of, and constrained by, the very material circumstances that it studies. It is this sense that Foucault tries to capture in the couplet "discourse/practice"; this is also the sense that 1 wish to communicate through the use of the term "discursive materialism." I shall give a brief example to clarify the use of this term. A given distribution of land ownership is usually thought of as a social relation of production. But the persistence of a specific land distribution is facilitated through a dense network of discursive practices-laws of property, landuse zoning, theories of land rent, efficiency of farm size, and so on. Thus an effort to reform a particular land distribution must overcome objections raised in discursive realms that are not directly connected to land ownership. So is landownership a social relation? a material relation? or a discursive relation? The answer is that it is all of these because it exists in a space of discursive materialism.

\section{Academic Relations and the Poverty Sector}

The category of academic relations in the nexus of production calls attention to the critical role of discourse in social construction (Figure 2). Of the two types of academic relations, internal and external, the former refers to the "internal" rules by which social science produces knowledge; the latter refers to the conditions under which specific discourses on 


\section{Academic relations of poverty}

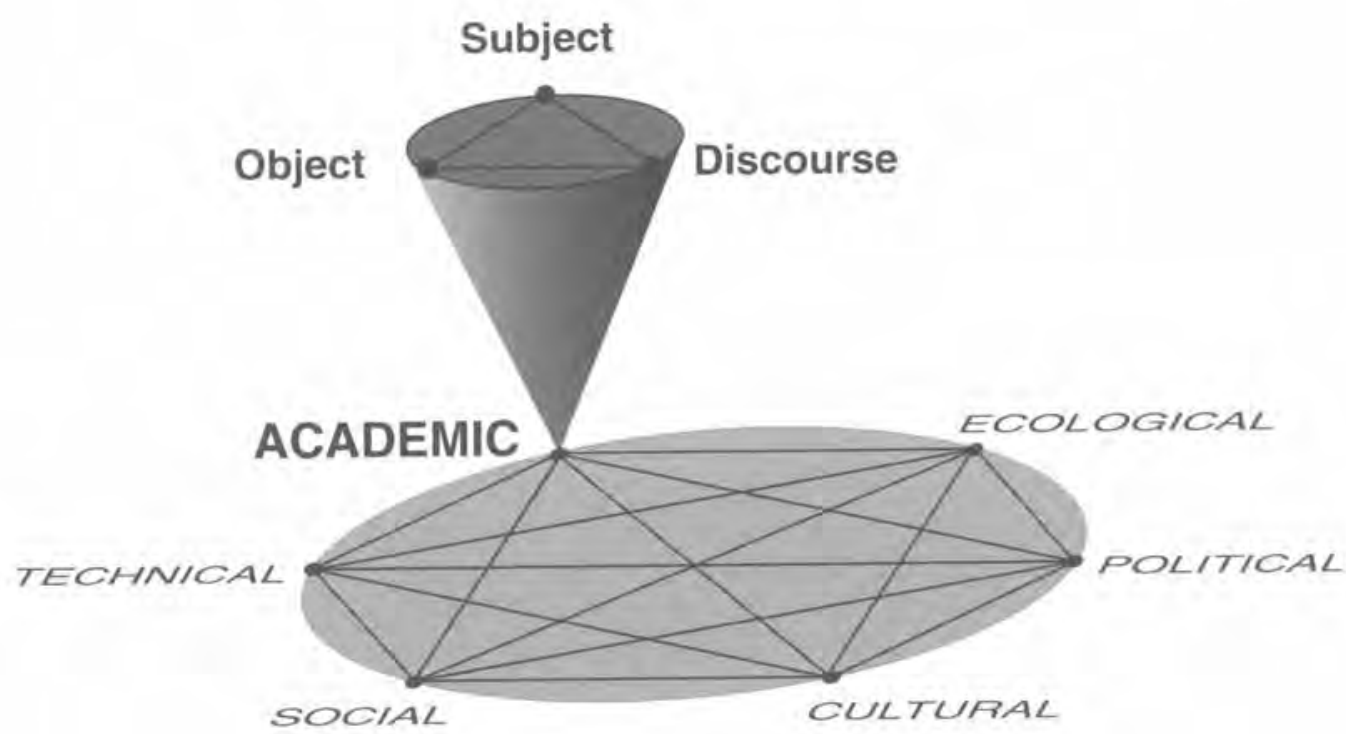

Figure 2. Academic relations of poverty where subject, object, and discourse are mutually constituted.

technology, culture, nature, and so on are produced. I shall use the notion of internal academic relations to link postmodern discourse and the nexus of production relations by focusing on a specific example, namely, the appearance of the subject/object binary in the conceptualization of a poverty sector.

Subject/Object Binary. Social science uses the term "subject" in a variety of senses: a subject as in social-science disciplines, a subject of inquiry, subjected to the power of another, subject as syntax, and so on. In this paper I refer to subject as thinking agent and as observer. In the specific context of poverty, the term refers to authors, professors, consultants, students, policymakers, extension agents, and even institutions such as the World Bank and the FAO (Food and Agricultural Organization of the United Nations). The term "object" refers to the thing or person being studied. Mainstream social science follows a model similar to that employed by the natural sciences in their studies of objects such as rocks, soil, heat, and light. Following this model, mainstream social science claims that its descriptions of culture, class, race, social mobility, poverty, and development are neutral, unbiased, objective, and value-free. Surveys and quantitative techniques are valued methods of analysis; these in turn demand a precise use of language to define analytical categories properly. The basic assumption is that the objects of inquiry contain stable internal characteristics; these can be objectively examined, and data can be collected to test hypotheses about these objects. The social-science investigator (the subject) stands outside the object employing a neutral discourse that studies the object (Natter, Schatzski, and Jones 1995). Of course, the relations between subject and object go beyond such functions of investigation; they also include diagnosis, policy recommendations, and the implementation of projects.

Postmodernism contends that the socialscience model representing its objects (e.g., class, race, social deviancy, the poor, lagging regions, etc.) is invalid on several important 
grounds. Objects of social science do not have "naively given" properties that are "just there" to be described by social scientists. The properties and language used in description are supplied by discourse. The object is constituted by the discourse; it is not independent. Foucault identified several "modes of objectification" through which objects come into being-"dividing practices," "classification," and "normalization." Institutions and their discursive practices are the agents by which objects (individuals) are divided, classified, and subjected to normalization. Consider the categories of normal versus mad, normal versus criminal, normal versus pervert, normal versus poor, modern versus traditional, and developed versus underdeveloped. They are the products of specialized discourses that determine the shape, form, and constitution of objects. Yet subjects too are constituted by discourse in a process Foucault called "subjectification." Cousins and Hussain (1984:101) described this aspect of Foucault's work thusly: "There was, as it were, a circular movement: the normal adult examined the 'abnormal' ... [and this provided a] vantage-point for his own analysis. That is, the relation of the subject to the object of knowledge in time turned into the reflexive relationship of self-understanding. As if it ... [were] the mirror in which the normal adult came to recognize themselves."

Of course discourse itself has no prior status independent of its relation to the subject/object binary (Figure 2). Discourse is produced by the subject in the acts of observing, constructing, and managing the object. The shaping of discourse thus was the central theme of Foucault's Madness and Civilization (psychiatry), The Birth of the Clinic (medicine), and Discipline and Punish (criminology). Other examples are the colonial construction of discourses on race, environmental determinism, and traditional culture (Livingstone 1992; Godlewska and Smith 1994; Blaut 1993; Said 1993; 1979).

Poverty Sector. In the poverty/development discourse the subject/object binary appears in the form of a statistical construction of a "poverty sector" - usually a set of households that fall below a given income criterion (Figure 3). This is the most popular approach to poverty used by the World Bank, the U.S. Cen- sus, United Nations' agencies, and national governments. Certainly, identifying households with low incomes helps administer social welfare where such programs exist. Such statistical description may also help in the targeting of households with specific nutritional or other special needs. The official approach to alleviating poverty consists of three steps: first, data are collected on the extent and the geographical location of poverty; second, information is gathered on "causative" variables such as race, gender, and employment that may be correlated with poverty; third, information on the incidence of poverty and correlated variables is used in models to help formulate appropriate policy and action. ${ }^{6}$ The notion of the "poverty sector" nicely illustrates the subject/object binary in social science: authors of poverty studies are subjects and poor people in the poverty sector are objects (Figure 3 ). Upon closer examination, however, this seemingly reasonable exercise of identifying the poor in the poverty sector appears not so reasonable after all. The subject/object binary in the definition of poverty sector goes to the heart of epistemology. According to official approaches, the poverty sector is where poor people are located, and, therefore, the locus of the "poverty problem." By viewing the poor (the object) as problem, the nonpoor (the subject) are automatically situated in the realm of the nonproblem. The nonpoor subject thus becomes the source of intellect, analysis, policy, resources, and solution. Using the concept of the nexus of rela-

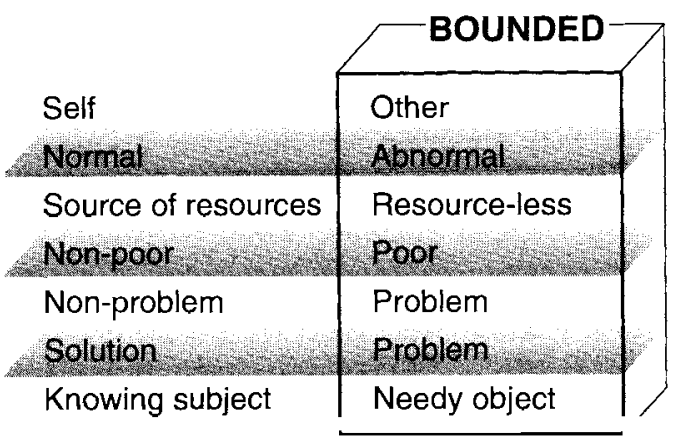

Figure 3. The dualism of the poverty sector: problem and nonproblem. 
tions, I will argue that the origin of deprivation experienced by the poor lies outside the socalled poverty sector.

According to the "dividing practices" of the official methodology on poverty, the subject emerges as a rational, compassionate, moral agent-the embodiment of self that possesses the intellectual and the material resources to solve the poverty problem. The poor emerge as the needy other-the object of study and compassion-in need of development. The status of the discourse, with its statistical profiles of poverty along with data on correlated variables, is nonproblematic. Postmodernists argue that matters are far more complex: discourse is not a neutral medium through which the subject obtains knowledge of the object; in fact, subject, object, and discourse are all mutually constituted. The form of each is simultaneously determined by the forms of the other two (Figure 2).

To illustrate the argument that subject, object, and discourse are mutually constituted, consider the social theory of the Green Revolution. This theory emerged out of the work of modernization theorists who classified farmers as "progressive" or "backward" depending on their response to high-input, high-yielding varieties of new seeds. In this instance, farmers were the objects, social theorists and extension agents the subjects. In South Asia, capitalist farmers with access to large areas of irrigated land and to capital for expensive inputs were transformed into "progressive farmers," while both poor farmers who could not afford to respond and intelligent farmers who actively rejected the new seeds for ecological reasons were transformed into "backward farmers." This was the language of the sociology of innovation diffusion, a discourse that came out of American rural sociology and that viewed favorably any technology that expanded farm output (Yapa 1993; Rogers 1969). The description of farmers as "progressive" or "backward" had little to do with the characteristics of the farmers themselves; these labels were mere names imposed on the farmers by the productivist logic of a technology discourse. Rural sociologists invented a language to promote the diffusion of innovation adoption; by virtue of their power to describe and classify farmers, rural sociologists became the locus of intellect and reason, and hence, escaped scrutiny.

\section{Discursive Construction of Scarcity}

\section{The Concept of Scarcity in Economics}

The official history of the economic development of nations is the story of material progress and expansion of production forces. But that history contains a parallel, unacknowledged history-a concealed history of socially specific and socially constructed scarcity. ${ }^{7}$ It is important to distinguish socially specific scarcity from the notion of general scarcity. Until recently the noun "scarcity" suggested an episode of shortage or a period of insufficiency (Achterhuis 1993:106). According to Xenos (1989) the concept of scarcity as signifying a general human condition was an invention of the cultural logic of modern times. The classical political economists Smith, Ricardo, and Malthus viewed scarcity as a general human condition. Marx himself was influenced by the idea; indeed, what is communism but a promise about abundance, a horn of plenty where people are freed from need? Some historians contend that scarcity is a discursive practice that arose with the birth of the political economy project of economic development; in the pursuit of ever more production and unlimited growth, nature was reduced to a field of scarce resources (Achterhuis 1993). To understand the problems of the poor, it is necessary that we turn away from the idea of scarcity as a general condition and view it as specific to particular social groups.

The notion of general scarcity forms the foundation of modern economics; what is deemed "the economic problem" is how to allocate scarce resources over unlimited wants (Heilbroner and Galbraith 1987). A popular American high-school text defined the subject in the following way (Applied Economics 1994:3):

.. if human wants are unlimited, but resources to
satisfy those wants are limited, then people in
every society face the same problem: the problem
of scarcity. . . [E]conomics can be defined as the
social science that describes and analyzes how
people in a society choose to use its scarce re-
sources to satisfy their needs and wants.

Economists present the notion of general scarcity as an overriding reality of nature and 
society, a notion that does little to help understand deprivation experienced by poor people. By assuming that limited resources are a state of nature and unlimited wants are a part of human nature, economists conceal the constructivist nature of scarcity.

\section{Scarcity Is Socially Specific}

Poverty is not experienced by society at large, but by particular social groups; it is a socially specific condition. For example, according to Bread for the World, a food-activist organization based in Washington, D.C., in the United States despite food surpluses, 20 to 30 million people face hunger at any given time (Hunger 1994). In Brazil-the largest country in South America, an important exporter of meat, soybeans, citrus fruits, and other agricultural commodities-one-third of its population is malnourished. Large numbers of children suffer from vitamin $\mathrm{C}$ and protein deficiencies, and in 1990 the infant mortality rate exceeded 60 per thousand. Yet that year Brazil grew sugarcane on over 4.26 million hectares of arable land, mainly for producing alcohol fuel for its large fleet of motor cars. A survey in northeast Brazil reported that the poorest fifth of urban households received less than 1,500 calories of food energy per capita, while the richest 10 and 1 percent were getting 3,300 and 4,290 calories, respectively (Harrison 1990:276). According to the World Bank (1993a:297), the share of Brazilian household income in 1989 of the poorest 20 percent of families was 2.1 and for the top 20 percent, 67.5 percent. Poverty in Brazil is thus a socially specific condition; it is not caused by a state of general scarcity in the economy (Bennet and George 1987:135161; Hecht and Cockburn 1990). ${ }^{8}$ The Brazilian case illustrates the classic attributes of poverty and development in the rest of the Third World: a high incidence of poverty even during periods of rapid economic growth; persistence of hunger in the face of increased production and surpluses and exports of food; promotion of export-cash crops while neglecting subsistence food crops; and slumdwellers and homeless in the midst of luxury housing.

\section{Resources Are Relations of Production}

Economists view resources as factor inputsland, labor, and capital-in production. The idea of limited resources assumes that "limits" originate in the intrinsic nature of resources, after all, there is only so much land, oil, coal, and capital in the world. But to alleviate poverty we need to look at "resources" in very different ways. I shall define a resource to be "something of value," but value does not reside in the "thing" itself; value is contextually mediated in a nexus of relations. For example, consider the potential productivity of a piece of land: the amount of calories and protein obtained from a single hectare of land growing rice or potatoes is very different by several orders of magnitude from that obtained by growing feedstock for chickens, pigs, or beef cattle (Akers 1989; Lappe and Collins 1977). ${ }^{9}$ A single hectare of arable land has no intrinsic meaning or fixed production potential; the substantive meaning of a single hectare depends not only on the characteristics of the parcel of land but also on who owns it and what use is made of it using which technology. It is simply misleading to speak of land as a factor of production that is fixed, and ignore the other myriad circumstances of land relations: inequality of land ownership (El-Ghonemy 1990; FAO 1987; $1988 ; 1990)$; use of good land for export cash crops such as sugar, tobacco, coffee and tea, and livestock (Lappe and Collins 1977; Hecht and Cockburn 1990); the productivity of small farms compared to larger farms; the yield advantages and the ecological sustainability of polycultures (Altieri and Hecht 1990; Altieri and Liebman 1986; Altieri 1987a; 1987b); and so on.

A given hectare has no a priori measurable "resource" meaning; its value is mediated in a nexus of relations, and will differ from one social group to another. Another example is the concept of a limited stock of capital, which is regarded as a hallmark of an underdeveloped country. Consider the case of a country needing a specific quantity of nitrogenous fertilizer each year. There are several technically feasible, alternative, and complementary ways of meeting this demand: the fertilizer can be imported each year from overseas; a fossil fuelbased fertilizer factory can be built in the country; a large number of local biogas plants using 
animal, human, or agricultural waste can be deployed; farmers can be encouraged to include legumes in their cultivation practices; and so on. Each practice, taken singly or in combination, has different implications for how much capital (and of what type) is needed. The actual practices finally adopted will depend on a large number of circumstances including the nature of the prevailing agricultural discourse, notions of progress and modernity, and the power of vested interests in import and construction sectors. As in the example of land, the notion of "limited capital" cannot be derived from an existing stock; what is capital, how much is required, and how much is available are all contextually mediated in a nexus of relations.

\section{Unlimited Wants Are Social Constructions}

The assumptions of unlimited wants and limited resources are the twin pillars holding up the economist's keystone of scarcity. In a market society the problem of scarcity is solved by meeting needs through marketable commodities whose production and consumption are regulated by price. But some have argued that the market is insensitive to the notion of "essential needs"; for example, the economists Lutz and Lux (1979) have complained that neoclassical economics has no theoretical way to distinguish between the importance of supplying drinking water and tobacco. In the 1970 s and 1980s, under the leadership of the International Labor Organization the official development discourse adopted a concept called "basic needs." ${ }^{10}$ Illich has been very critical of this turn of events; in his words (1992:88), "Basic needs may be the most insidious legacy left behind by development." He objected to a basic-needs strategy on the grounds that it obscures cultural differences and builds expectations on bureaucratic systems that will deliver nutrition and health care. Although llich (1978) does not use the language of postmodernists, his writings are troubled by a scheme that legitimizes the subject/object binary-with a needy poverty sector as object, and the development theorist, technical specialist, and service provider as subject.

The endless construction of need is an essential social relation of capitalist production because economic growth depends on the production of new goods for new markets. "By definition, ... the rich of the world, are already satisfying their needs of material subsistence. If they are to spend their surplus, which they must if the economy is to grow, new goods must be produced which they [the unrich] must be induced to want. ..." (Elkins 1986:55). The twin processes of creating new needs while creating dissatisfaction with existing ways of satisfying needs are an "important motor of the growth economy." ${ }^{\prime 11}$ The acceleration of consumption driven by the imperatives of economic growth often manifests itself in cultural forms -in changing fashions, "keeping up with the Joneses," our notions of success and social mobility, symbols of status, and the ideology of modernity.

The social construction of wants occurs at all nodes of the nexus of production relations. I shall clarify the point with a few examples. A part of the demand for chemical fertilizer (the need for) is created by technical decisions to promote it while neglecting or even discouraging other practices such as crop rotation and biogas production. Similarly, the high household demand for gasoline in the United States is driven by many factors among which are the heavy use of private automobiles necessitated by the lack of transport options such as buses and bicycle paths. At the ecological node, wants are constructed in at least two ways: 1) by substituting industrially processed commodities for use-values created in nature, for example, the promotion of infant formula as a substitute for breast milk; and 2) by the development of items designed to alleviate the degraded quality of the environment, for example, air-pollution abatement equipment. The semiotic theory of signs, and particularly the concept of polysemy, are useful ways of investigating the links between social and cultural relations of commodity production (Gottdiener 1994; Goldman and Papson 1994; Kellner 1991). The concept of polysemy refers to the ambiguous nature of signs in cases where numerous interpretants intercede between the sign and the object. Modern advertising creates desire and new wants by introducing new pathways into the "polysemic space" of signs and the objects they signify. Encoded objects are appropriated by the economy, and their exchange value is maximized by marketing 
schemes where the relation between use- and exchange-value is mediated by numerous signvalues (Gottdiener 1994:172). ${ }^{12}$

\section{Constructed Scarcity: A Substitution Model}

Among the numerous ways in which scarcity is constructed, one of the most important, the concept of substitution, may be illustrated by a simple graph of demand and supply curves for a commodity ${ }^{13}$ Assume that a particular need (consumer or producer) can be satisfied in several alternate or complementary ways as shown by the different elements is the set $\mathbf{A}=$ $\left\{a_{1}, a_{2}, \ldots, a_{*}, \ldots, a_{k}\right\}$. The graph in Figure 4a shows the demand and supply curves, $D_{A}$ and $S_{A}$, for the sum of all elements of the set A. The curve $S_{A}$ should not be confused with the supply curve of an industry aggregated from the individual supply curves of firms; it should be thought of as a hypothetical curve representing an aggregate made of distinct and disparate sources and means of supply. For example, suppose that $S_{A}$ is the aggregate supply curve of nitrogenous fertilizer in a region that is made up of several different types of supply-chemical fertilizer, biogas slurry, agricultural waste, animal manure, leguminous crops, and so on. For the sake of argument, assume the existence of mechanisms in society that restrict the availability of members of the set $\mathbf{A}$ except $a_{*}$ which, for illustrative purposes, is chemical fertilizer. The net effect of such restriction is to produce new demand $\left(D_{*}\right)$ and supply $\left(S_{*}\right)$ curves for the element $a_{*}$, that is, chemical fertilizer, with price $P_{*}$ and quantity $Q_{*}$ (Figure $4 b$ ). The specific demand and supply for $\left(a_{*}\right)$ have simply replaced the old demand and supply for the entire set of elements in A. In this model, social construction of scarcity occurs at several points: a new increased demand has been created for a specific good; alternative ways of supplying the need satisfied by that good have been eliminated; and some social groups may pay a higher price than before to satisfy that need. Many poor agricultural communities of the Third World provide examples where some of the eliminated alternatives involved prices that simply reflected the cost of their own labor. In a society where incomes are highly unequal, removing alternate sources of supply may cause absolute scarcity for those at the bottom of the eco-

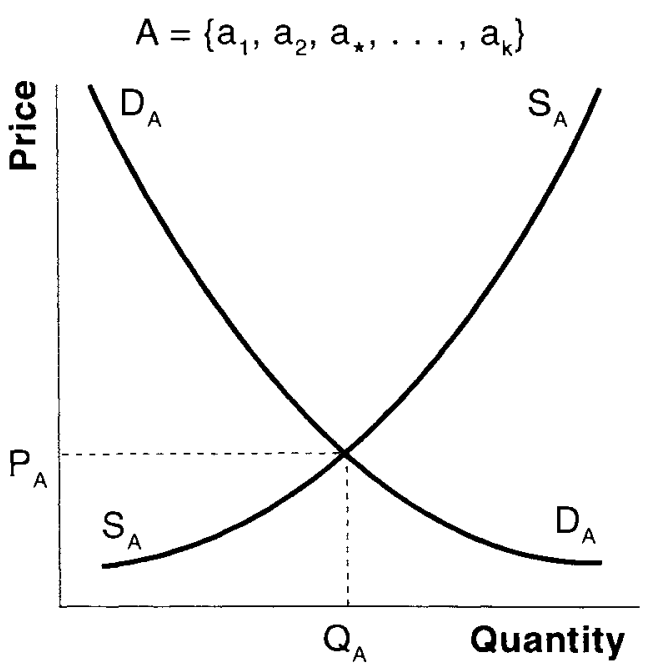

Demand and supply curves for $A$

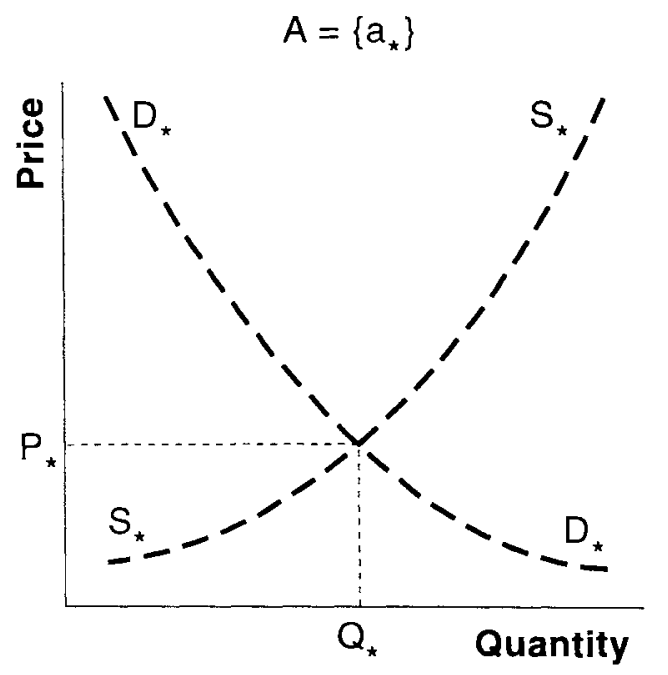

Demand and supply curves for $A$ note: $a_{*}$ is now the only element of $A$

Figure 4. Substitution as a mechanism in the construction of scarcity. 
nomic ladder. As explained earlier, mechanisms that create such scarcity in society exist at all nodes of the nexus of production relations (Figure 1). This explains the paradoxical Januslike nature of economic development-even as development creates some use-values, it destroys others simultaneously.

Economics takes scarcity as its object of study. But where does scarcity actually exist? It exists in a space of discursive materialism because it is constituted from particular discourse/practices. Why is it important to say that, or use this uncommon language? If scarcity is implicated in discourse, then we cannot hope to alleviate poverty without first making the dominant discourse, academic economics and its derivatives such as economic geography, the object of our study. This is what Foucault refers to as the problematic of society as both the object and subject of social science. Recognizing this is what 1 mean by the postmodernization of social science.

\section{Discourse, Power, and Poverty}

Foucault has expanded our understanding of power in two important respects that are helpful for thinking about poverty - "disciplinary" power and "sovereign" power. The notion of disciplinary power runs through much of Foucault's lifework exploring how power is exerted through disciplines such as psychiatry, medicine, and criminology. In his later writings Foucault argued that our understanding of political power was unnecessarily circumscribed by notions of "sovereign" power. I have used these two conversations about power to redefine what is meant by seeking a "solution" to the "problem" of poverty. This section of the paper contains three themes: First 1 question how the problem of poverty is conceptualized by using the view of disciplinary power to explore how cause, action, and agency are mutually constituted from discourse. Second I point out that the idea of a "solution" is a part of a metanarrative that reifies the problem in a manner that is unhelpful to addressing poverty. Third I suggest that the substantive approach to poverty advocated in this paper is a special case of Foucault's more general view on the "nonsovereign" nature of power.

\section{Mutuality of Cause/Action/Agency/Power}

Representing Poverty. We have seen that it is crucial to distinguish between poverty as a material condition experienced by the poor and its representation in the academic literature of social science. In these cases representation is part of the problem. There are three noteworthy features of the conventional academic representation of poverty. First, poverty is conceived as a concrete material condition and ascribed the status of a dependent variable in the analysis. Second, a list of causative factors (or independent variables) that may vary from study to study is invoked to explain poverty. ${ }^{14}$ Third, suggestions to solve the problem are based on actions that manipulate what are deemed to be the more important causative agents. This three-step procedure follows the logical canons of problem solving: state the problem clearly, identify the causes, and seek a solution by designing a plan to exercise control over the presumed causes.

"Poverty as discourse" is a conceptual abstraction that groups together several material states of deprivation, e.g., hunger, homelessness, and ill-health. Such an abstraction is useful if it helps us address the problem of poverty, but when it fails, this conception should be replaced by more concrete considerations of food, shelter, and health. The concrete question "What causes hunger, homelessness, and ill-health?" yields substantially different answers from those we get from the question "What causes poverty?" The latter focuses on levels of income that are insufficient to buy a market basket of basic goods. The focus on income is based on the connection that more affluent people have adequate food, shelter, and health care, hence the belief that problems of poverty will disappear with economic growth and the consequent growth in household income. This concern is most often operationalized through another question: "Why do some households have low incomes?" This question invites the use of variables such as urban/rural location, region, employment, ethnicity, education, sex of the head of household, and so on (World Bank 1990; 1993b; 1993c; Central Bank of Sri Lanka 1987). On the other hand, questions framed around the social construction of scarcity (e.g., Why are these specific people in this region experiencing malnutrition?) yield very different answers. Which re- 
search question is asked has many nontrivial implications about the actions that will be taken and the agents who will take such action. When we adopt the poverty-sector approach, poverty is exteriorized as a bounded object that resides in particular households and places. What is more, the instant we adopt that idea we have also embraced a linear and tightly linked epistemology of cause, action, agency, and power.

Overdetermination. Let us now turn to the notion of causality employed in the literature on poverty and development. Poverty (read low income) is the selected object of study and other objects of study (independent variables) are invoked as causes of poverty. This notion of causality has been called "essentialism"; philosophers have also employed the terms "determinism" and "reductionism" to describe the approach. In the words of two Marxist economists, Wolff and Resnick (1987:15):

[These terms] refer to the presumption that any event can be shown to have certain causes or determinants that are essential to its occurrence. Essentialist (or determinist or reductionist) reasoning proceeds as follows: (1) when event A occurs in society, we know that an infinite number of other events are occurring simultaneously and that an infinite number of other events have occurred previously; (2) we presume that a few of this vast number of other events were the key, chief, "determinant," or "essential" causes of $\mathrm{A}$; and (3) we therefore define theoretical work as separating the essential (determinant) from the inessential (nondeterminant) causes. The result is an "explanation" of A: the cause of A has been reduced to its final determinants. Hence the term "reductionism" refers to theories that reduce the explanation to events in the world to a few essential causes.

For the purpose of this paper I wish to follow a notion of causation that is described in philosophy as "overdetermination." In this view, no one aspect of society, and certainly not the economic, is assigned priority over others. It is assumed that all aspects of society mutually shape one another. This concept is similar to the idea of the nexus of production relations where relations interact and are mutually constituted. Again Wolff and Resnick (1987:134) offer a succinct description of overdetermination:

Thinking in terms of overdetermination means that each aspect of society is approached as the combined effect of all the other aspects of that society. This idea is best described by the word "constitu- tivity." Each aspect of society is constituted-literally created--as the combined effect of all other aspects. Thus no aspect can exist independently of the others, which create it. No one aspect can exist prior to the others as, for example, their ultimate cause.

Economism. Poverty is represented in the development literature as essentially an economic problem: People are poor because they do not have enough money to command a market basket of basic goods, a situation that can be corrected through investment, growth, job creation, improved education, and so on. Within the academic terrain, the discourse on poverty has been constructed at a particular theoretical locus whose principal defining characteristic is economism, the dominant worldview of the social order composed of a market at the economic base, a superstructural value system to facilitate the working of the market, and an academic discourse constructed to rationalize the general commodification of use values. This I maintain is a reductionist argument because it has reduced the lack of food, shelter, and health care to an economic problem that in turn calls for economic solutions. By defining poverty as an economic problem, as a lack of, we are prevented from seeing how the scarcity of basic goods is socially constructed at a large number of sites at every point on the nexus of production relations. For example, there are a number of ways of improving the nutrition of lowincome families. These include reducing the purchase of expensive processed foods, establishing cooperatives to encourage bulk buying of produce, giving access to community kitchens, raising food in home gardens, and, in rural areas of the Third World, disseminating knowledge of edible leaves and plants with food value. We can make similar arguments for a range of topics such as food production, building of shelters, provision of health care, education, and transportation. We foreclose a myriad of options and possibilities by approaching poverty as an economic problem related to income, and thus prevent the resolution of the very problem that we are trying to solve.

The Consequences of Choice of Theory. The relation between social theory and society is a two-way street. Not only do theories shape society, but society shapes theories, and thereby shapes itself. The nature of this mutu- 
alism can be explored by tracing analytically the mutual constitution of causation, action, agency, and power. Social theory's search for the causes of problems is primarily a discursive matter of choice of paradigms. Neoclassical economics emphasizes individual behavior, rational self-interest, markets, productivity, and income. Marxian theory emphasizes social structure more than individual behavior and calls attention to class exploitation as a causative agent (Peet and Watts 1993; Pickles and Watts 1992). Choice of theory leads to different research designs, variables, and diagnosis of problems. It is not true that social science merely uncovers how naively given causal agents function in the material world; causal agents are theoretically selected, discursively constructed, and socially sanctioned.

An example clarifies the point. The development literature of the postcolonial period placed a heavy emphasis on land reform as a means for increasing agricultural productivity and reducing the concentration of political power of landed interests. In the 1970s, the World Bank under the leadership of Robert McNamara "accorded high priority to agriculture in general, and land reform and rural poverty in particular, between 1972 and 1980. It was the golden age, so to speak, of these rural development policy issues, both intellectually and operationally" (El-Ghonemy 1990:59). At this time among the World Bank (1974:10-11) guidelines on lending were the following: 1) The Bank will give priority in agricultural lending to those member countries that pursue broad-based agricultural strategies directed toward the needs of the poorest groups. The Bank will support policies of land reform designed to further these objectives; 2 ) In circumstances where increased productivity can effectively be achieved only subsequent to land reform, the Bank will not support projects that do not include land reform. A decade later (as evident in successive issues of the World Development Report, a key annual publication of the World Bank), land reform as a policy goal in poverty reduction has disappeared from the development discourse. This change in World Bank thinking had little or nothing to do with a decline in land concentration around the world, and had a lot to do with changes in economic and foreign policy instituted during the years of the Reagan-Bush presidencies. ${ }^{15}$
What such examples show is that choice of social theory, or what amounts to the same thing, the choice of explanatory causes, will determine what practical actions may be taken for the alleviation of poverty. ${ }^{16}$ In turn, the sorts of actions selected determine who is authorized to act, who shall wield power, and, consequently, who shall not. Every social theory of causation is simultaneously a command for the allocation and use of power. ${ }^{17}$

Consider another example from a World Development Report (World Bank 1992) endorsing the concept of sustainable development as stated in the Bruntland Commission 1987 Report Our Common Future. The Bruntland Commission declared that the environmental degradation of poor countries was attributable, in part, to the lack of ecologically benign technologies; the Commission recommended the transfer of appropriate technology developed in the West. Since the lack of technology was deemed as a cause of the problem, transfer of technology became the appropriate action. This in turn determined the agents empowered to act: research universities, companies, international aid agencies, consultants, and technology extension services (in postmodern language we call this "the birth of the subject"). As an example of technology transfer, The World Development Report of 1992 (1992:65) referred to integrated pest management. "Poverty, uncertainty and ignorance are the allies of environmental degradation ... . better educated people can more readily adopt environmentally sound but complicated techniques such as integrated pest management." Integrated pest management involves using a combination of methods: cultivation methods such as crop rotation and interplanting; biological methods of prey/predator relations; cultivating resistant varieties; and pesticides. Many Third World farmers have been practicing nonchemical methods of pest control for hundreds of years; in fact, the widespread use of pesticides on food crops did not begin until the Green Revolution. There is much to be learned from indigenous knowledge systems of pest control (Altieri 1993; Ulluwishhewa 1992; Warren 1990). Moreover, nonchemical techniques are very place-specific and closely adapted to highly local conditions. These are not "package technologies" that are amenable to technology transfer. In light of this, the World Bank pronouncements on the transfer of integrated pest 
management to the poor borders on arrogance, a knowing subject pronouncing on the needs of the needy object. Besides, such attitudes devalue local knowledge and marginalize the role that peasants can and do play in agricultural change.

\section{Repudiating Solutions}

Solution as Metanarrative. To resolve the problems of the poor it is first necessary that we abandon the frame of mind that demands a "solution to the problem," that we entertain a postmodern incredulity toward metanarratives (Lyotard 1979). I believe that the concept of "a solution to poverty" is a metanarrative in itself. Yet hunger and homelessness are real; if development is not the answer, then what is? In my view it is simply wrong to equate the terms "development" and "solution" because they are mutually antagonistic concepts. First we must be willing to entertain the hypothesis that development creates scarcity (Yapa and Wisner 1995; Sachs 1992; Esteva 1992). If development creates scarcity, then it cannot be true that lack of development (underdevelopment) is the cause of poverty. What is important is to pay careful attention to the way the argument against development is structured, and to understand the specific details of the critique. Any resolution of the poverty problem can arise only from knowledge of the details of that critique. Of course, at the same time we must resist the temptation to tell still another grand narrative-the story of a new societybased on visions of alternative, authentic, or sustainable development, of "another" development, or even a postdevelopment era. The danger is that since development is a grand idea to begin with, an "alternative solution" must appear to be equally grand to measure up to the task.

We have seen how scarcity is created through the complex interplay of multiple relations, where no single force emerges as more "essential" than another as an explanatory cause. It is clear that the economist's working concept of the poverty sector cannot encompass the multiple sites at which scarcity is created. In fact, many of the discursive and non-discursive practices that induce scarcity function deep inside the sector of the nonpoor. The existing poverty discourse directs our at- tention to a conceptualized space that is not useful from the practical point of addressing the question of basic needs. Identifying families whose income falls below specified criteria does help us properly administer incomemaintenance and welfare programs, but not much more. Poverty is a discursive/materialist formation. There is no real substantively bounded space called the poverty sector that can present itself as a tangible target for the economist's "assault-on-poverty." In fact, the concept of the poverty sector has diverted attention away from the complicity of development in the social construction of poverty.

Poverty as a Substantive Network. I propose that we begin by replacing the reified notion of the poverty sector with a discourse that is postmodern, contextual, place-specific, and substantive. We need to ask substantive questions. For example: "Why do people in particular places lack enough food to eat?" Such questions can be approached via the nexus of production relations in order to investigate the discursive and nondiscursive practices that create scarcity at each node. ${ }^{18}$ If the causes of poverty are multiple then it can be confronted at multiple sites-in technology, culture, ecology, politics, and academia as well as in the economy. I illustrate this idea by using a tree diagram (Figure 5) in which the notion of a poverty sector is replaced by a list of items in a basic basket of household goods: food, clothing, shelter, health care, transport, and so on. Each basic good is embedded in a nexus of production relations which ultimately is a vast network of discursive and nondiscursive relations. To proceed, suppose we arbitrarily begin with the topic of food (Figure 5) and from there to the technical node with its list of food production inputs: fertilizer, water, seeds, machines, and so on. Note that each item in this list is further embedded in its own nexus of production relations. From the list of technical inputs, imagine that we choose "fertilizer." At this level of the hierarchy, we are confronted with alternative methods of providing soil nutrients, each of which is embedded in its own nexus of relations. Note that every subtopic is continually embedded in a nexus appropriate to its scale (=overdetermined). At the level of soil nutrients we can begin to explore how scarcity-inducing mechanisms work through a network of discursive and non- 


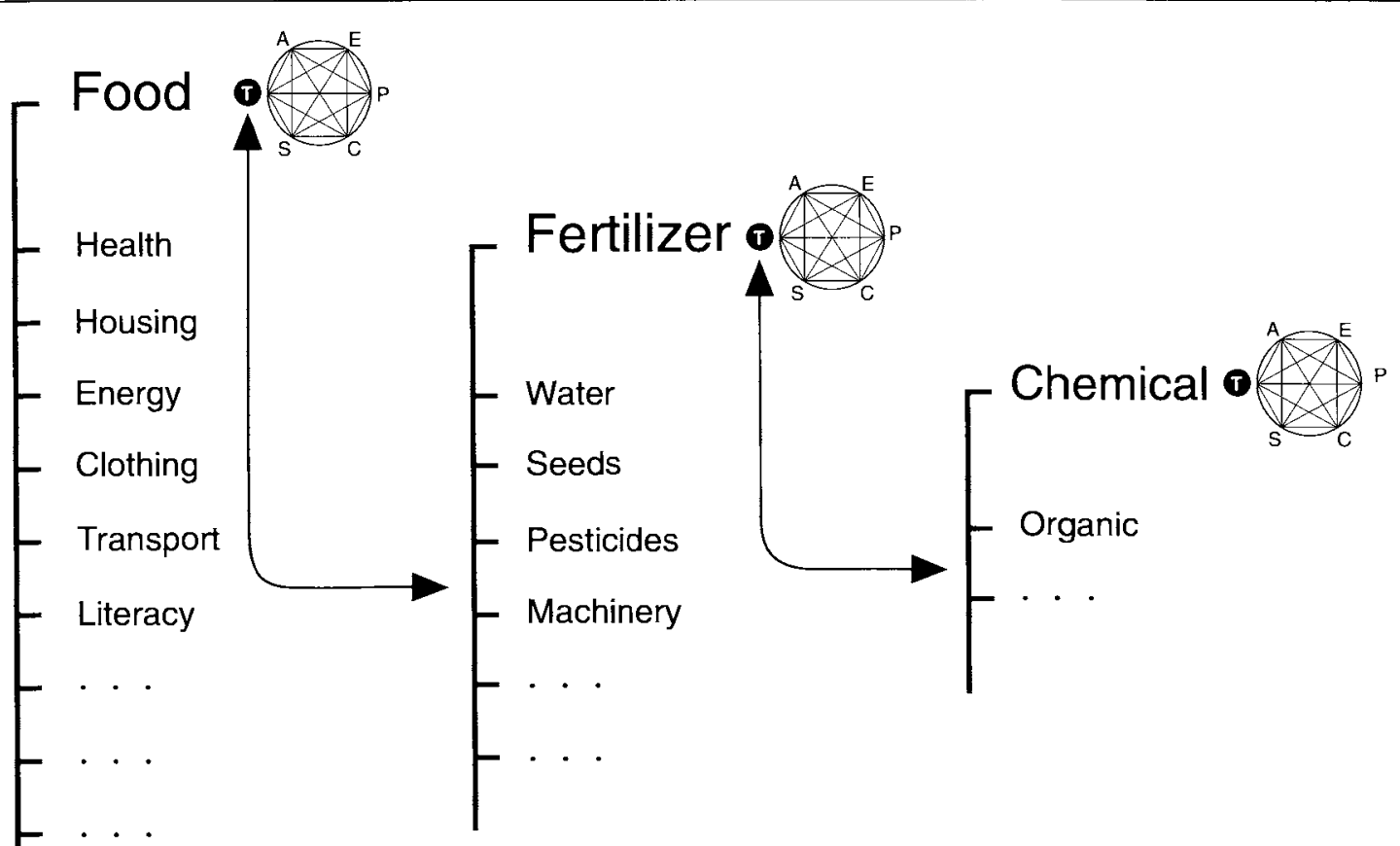

discursive practices. Chemical fertilizer, agricultural residues, biogas slurry, crop rotation, interplanting, and so on are all alternative or complementary ways of providing soil nutrients. Each technique has scarcity-inducing implications in terms of money and labor costs, and ecological, cultural, and political relations. In this example we followed a path defined by food/technical/fertilizer/technical/chemical, but we could have just as easily chosen a different branch through the tree diagram, e.g., by starting at a different basic good and following any other path in the relations of production. Each path provides unique sets of possibilities and of action agents. The resolution of the poverty problem in a given region will come, 1 believe, from considerations of the substantive details among numerous paths of this sort.

The concept of the poverty sector is a discursive convention that serves no useful purpose in the resolution of the poverty problem.
There is no coherent body of phenomena called poverty whose inner nature can be revealed by studying people who are deemed poor. The causative relations of poverty exist in a dense network of scarcity-inducing discursive and nondiscursive relations. By concealing that, social-science discourse hinders the alleviation of poverty at many levels. It is not possible to describe "a solution" to poverty in a manner demanded by the question, "What is your solution to the problem?" The problem's resolution requires substantive action at multiple sites spread throughout the nexus of production relations at various levels of the topic hierarchy (Figure 5). An important part of that action is what I have called the postmodernizing of social science. The description of causative relations and spaces for action in poverty alleviation leads us to the following kinds of inquiry, "Who are the new agents of change?" "What actions will they take?" and "What capacity or power do they have to act?" 
By moving away from an abstract general notion of poverty, we eliminate or reduce the influence of "poverty experts" in the discourse. By moving away from the economistic logic of more income and jobs, we reduce the authority accorded to economists as "experts on the subject." By decentering the poverty expert as subject of the discourse, we mobilize the resources of a large number of other agents of change who have substantive knowledge of how scarcity is constructed in their fields of experience, e.g., 1) scientists in low-input sustainable agriculture, alternative energy systems, architecture, and urban design; 2) artists, critical cultural theorists, and journalists; 3 ) keepers of indigenous knowledge in agriculture and health care; 4) community leaders; 5) farmers; and so on.

\section{Nonsovereign Power and a Substantive View of Poverty}

Our conventional understanding of political power comes from two main sources-political science and Marxism. In this view power is seen as a force unto itself: some have it, others do not. Like money, it can be acquired, accumulated, exchanged, brokered, and used; some classes have more of it and others less; and the state has most of it and so on. Political science locates power at the center within institutions such as the parliament and the congress; political activity is associated with voting or working for a party. Marxists locate their understanding of power in political-economy theories of class and state (Nandy 1992). Foucault calls these the "sovereign" view of power.

Foucault argued that this mainstream view of power can be characterized as one of sovereignty/obedience. In Foucault's words (1990: $85)$, "[it does not matter] whether the individual in question is the subject opposite the monarch, the citizen opposite the state, the child opposite the parent, or the disciple opposite the master. A legislative power on one side, and an obedient subject on the other." The characteristics of the sovereign view of power have their roots in liberal politics that arose in opposition to the power of the monarch in the eighteenth century; this is a "juridical" conception of political power because it emphasizes law and rights (Foucault 1980:88). Foucault ar- gued in behalf of a richer, more complex view of power than that contained in the construct of juridical sovereignty. He advocated (1980:120) a nonsovereign view of power: "What we need ... is a political philosophy that isn't erected around the problem of sovereignty, nor therefore around the problem of law and prohibition. We need to cut off the King's head: in political theory that has still to be done."

Foucault's thoughts on sovereign power are scattered over a wide span of his writing; the brief summary that follows is drawn mainly from his volume, The History of Sexuality (1990:80-92): Nonsovereign power is not exclusively possessed by a dominant class, or the state; there is no great divide between rulers and ruled. Power is not always imposed from above because it can come from below. In fact, the state draws its power from below-from production, from families, from groups, from institutions-in a capillary fashion. Power relations are not secondary to other types of relationships such as economic processes, knowledge relations, and sexual relations; power relations are constituted from and immanent in the latter. Power is employed and exercised through a netlike organization; individuals are not only the consenting targets of power, but they are also the elements of its articulation. Power is in play in small individual parts and it is exercised in concrete actions from innumerable points. Hence there are creative productive points of resistance everywhere in the power network. There is "no single locus of great Refusal," no soul of revolt, no grand project that is global or revolutionary.

In this paper I have argued for a substantive approach to the question of the poverty problem. This approach maintains that agents of change act not through a general exercise of power, but by exerting their will in a "netlike organization" in particular substantive issues of food, nutrition, housing, education, transport, culture, geographical location, and so on (Figure 5). Thus there are as many points of resistance as there are points of power; it is not helpful therefore to reduce that plurality (both in numbers and in substance) to a single abstract struggle against the state. Moreover, each of these substantive issues is informed by powerful discourses (e.g., "good nutrition," "scientific agriculture," and "suburban living") 
that shape the social construction of scarcity. Power to resolve the poverty problem must have the capacity to counter the power of scarcityconstructing discourses that circulate throughout society. Clearly, juridical or sovereign notions of power do not serve that end. Foucault's concept of nonsovereign power reaching into every crevice of the micro-sociology of society is thus identical to the concept of power implicit in the substantive approach to poverty advocated in this paper (Figure 5 ).

\section{Location of the Author}

My view of "development as discourse" differs radically from other perspectives on development-free-market, socialist, environmentally sustainable, grassroots development, and so on. "[S]uch analyses have generated proposals to modify the current regime of development: ways to improve upon this or that aspect, revised theories or conceptualizations" (Escobar 1992:25). In the conventional paradigms of development the object of study is the poor themselves; strange as it may seem, the poor are not the object of study in this paper, at least not directly. My object of inquiry is discourse: it is about the academic business of studying, defining, analyzing, writing, and speaking about the poor. This shift of focus is not simply a matter of linguistic and discursive convention; it is because the material conditions of the poor are causatively linked to the discourse about them.

"Location of the author" has at least two meanings: one is the sense of author as subject-as in the academic triangle of subject, object, and discourse. The other sense is more personal: if I were to discuss "poverty" at a particular place and time, what topics will 1 choose to examine, what techniques of investigation will I use, what political and moral values will I bring to bear on the research? Important as it is, I have chosen not to locate the author (myself) in this personal sense. This is because the primary object of the paper was to show how the author as subject of the discourse on poverty and development is deeply implicated in the social construction of scarcity.

I conclude by locating my authorship in the context of discourse and the resolution of the poverty problem. The power of an author has two dimensions: one is derived from the discursive network extending from the theoretical selection of causes to actions, agency, and power; the other springs from institutional identities of the author, as for example, a university president, a politician, a business executive, and so on. In my case the power that I wield as author is primarily discursive; likewise, my institutional identity as a university teacher puts me even closer to the discursive realm. Although this paper is about poverty, the object of inquiry is not the poor but the academics who teach and write about the poor. I have chosen academic discourse as object for two important reasons. First, discourse is, in my opinion, a part of the problem of poverty. Second, my ability to act in the world, to exercise power, has to be commensurate with my power as a teacher and author. I now return to the perennial question posed by my students, "What is your solution to the problem?" My response is that I wish to shift the focus from the notion of a "solution in the world" (which is the intent of the question) to the notion of "your/my solution." The "academic" work that I do on poverty is "my solution;" it is the "practice" of my politics. My "solution" does not treat the poor as a target group; in that sense, this particular academic work will not make any immediate material difference to the lives of the poor, although there is nothing to prevent academics (and many do) from playing interventionist roles. Nor is this work aimed at state bureaucrats whose role it is to design poverty policies. "My solution" is aimed at fellow academics who, like myself, are deeply implicated in the problem and whose power lies primarily in our capacity to engage the discourse critically.

\section{Acknowledgments}

I wish to thank the Deasy GeoGraphics Lab of the Department of Geography, Pennsylvania State University for help in producing the graphics.

\section{Notes}

1. An extreme statement of the postmodern condition comes from Baudrillard (1993). He argues that in today's world of information, TV, and simulation, signs no longer have stable points of 
reference. Signs do not represent reality; they create their own reality. There is no real world to represent because there is no original to copy from. Everything is a copy of a copy of a copy-a simulacrum. Disneyland is authentic because there is no real distinction between the real and the model.

2. Some scholars use the term "poststructuralism" as the equivalent of the "postmodern as attitude" (Escobar 1995; Sarup 1988; Natter and Jones 1993).

3. According to Escobar (1995:130), "representations are not a reflection of 'reality' but constitutive of it. There is no materiality that is not mediated by discourse, as there is no discourse that is unrelated to materialism."

4. Not all authors cited here will care for the appellation "postmodern." But as in all complex intellectual formations, postmodernism has drawn nourishment from diverse, often contradictory and even unwilling, sources.

5. Essentialism is the presumption that among the influences producing an outcome, some can be shown to be nonessential to its occurrence while others can be shown to be the essence, or the essential causes (Graham 1990; 1992; Peet 1992).

6. I do not mean to imply that all models of poverty employ the logic of statistical regression.

7. The development literature contains hundreds of examples of what I have called socially constructed scarcity in food, health, housing, transport, and access to land: processed food such as infant formula and breakfast cereals (Wisner 1988; Lappe and Collins 1977; Trainer 1994; Timberlake 1986); grain-fed livestock (Akers 1989); input-intensive high-yielding seeds (Yapa 1993; Shiva 1991); pesticides and fertilizer (Bull 1982); loss of genetic diversity (Mooney 1979); neglect of indigenous knowledge (Chambers 1983; Rocheleau 1991; Carney 1993); emphasis on private motor cars and urban highways for commuter traffic; deprivation caused by incessant rounds of structural adjustments (George 1992; Payer 1991); restricted access to land (Hecht 1985; Carney 1993); and so on.

8. For an excellent analysis of the social specificity and social origin of hunger in West Africa, see Watts (1983a; 1983b).

9. In 1992, 37 percent of the grain used worldwide was fed to livestock and poultry. In 1990, the share of grain fed to animals was 55 percent in Brazil, 62 percent in Taiwan, 31 percent in Mexico, and 20 percent in China (Brown, Kane, and Ayres 1993:36).

10. During this time Robert MCNamara led a major initiative at the World Bank focused on basic needs. Similar efforts at the U.S. Agency for International Development were aimed at the "poor majority."

11. In 1988 according to Kellner (1991:66), more than $\$ 102$ billion (about 2 percent of U.S. GNP) was spent on advertising. Roughly an equal amount of money was spent on design, packaging, and marketing. The scarcity I speak of involves not only the proliferation of new wants and higher prices paid for use-values, but also the opportunity costs of such wasted resources.

12. Advertising constitutes one of the most advanced spheres of image production; more money, talent, and energy are invested in this form of culture than practically any other in our society. Advertising itself is a pedagogy that teaches individuals what they need and should desire (Kellner 1991).

13. I thank Kurtis Fuellhart of Pennsylvania State University for discussing and clarifying my understanding of this idea.

14. This characterization should not be misconstrued to mean that all such studies follow a statistical regression design.

15. According to El-Ghonemy (1990:29-32), results of surveys taken between 1978-1984 show that land concentration increased in several Third World countries.

16. In a book on the causes and politics of cancer, Proctor (1995:14) observes: "The concept of causation is part of the problem: much of the politics of cancer research lies in how far down in the chain one is willing and able to look." Proctor has shown that the causes that are selected for study have major consequences for the funding of research, for what is known and what is not known, and for what practical measures are adopted and who is authorized to act.

17. There is now a very large literature showing how power affects research priorities, and, therefore, what we know and what we do not know. The following are examples: pesticides (Van den Bosch 1978); crop research (Hightower 1973; Kloppenburg 1990; Hewitt de Alcantara 1976); agricultural research (Busch and Lacy 1983); international agricultural research centers (Jennings 1988; Anderson, Levy, and Morrison 1991; Oasa 1987); military and foreign policy (Dickson 1988); and cancer research (Proctor 1995). I have found useful the following general sources on the theme of knowledge and power: Aronowitz 1988; Proctor 1991; Rouse 1987; Foucault 1980.

18. Several objections can be lodged against such an approach. One is that the task of investigating practices at multiple sites is so large that it will delay attending to the urgent business at hand. Another is that this approach's refusal to separate the essential from the nonessential leads to indecision and weakens the base of political activism (Peet 1992). As 1 have tried to show, such objections are based on a fundamental misunderstanding of the nature of causation and poverty.

\section{References}

Achterhuis, H. 1993. Scarcity and Sustainability. In Global Ecology, ed. W. Sachs, pp. 104-116. London: Zed Books.

Akers, K. 1989. A Vegetarian Sourcebook. Denver, Colorado: Vegetarian Press.

Altieri, M. A., ed. 1993. Crop Protection Strategies 
for Subsistence Farmers. Boulder, Colorado: Westview Press.

. 1987a. Agroecology: The Scientific Basis of Alternative Agriculture. Boulder, Colorado: Westview Press.

1987b. Experiences in Success: Case Studies in Growing Enough Food through Regenerative Agriculture. Emmaus, Pennsylvania: Rodale International.

Altieri, M. A., and Hecht, S. H., eds. 1990. Agroecology and Small Farm Development. Boca Raton, Florida: CRC Press.

Altieri, M. A., and Liebman, M. 1986. Insect, Weed and Plant Disease Management in Multiple Cropping Systems. In Multiple Cropping Systems, ed. C. A. Francis, pp. 183-218. New York: Macmillan.

Anderson, S., Levy, E., and Morrison, B. M. 1991. Rice Science and Development Politics. New York: Oxford University Press.

Applied Economics. 1994. Applied Economics: Junior Achievement Curriculum for High School. Publisher unknown.

Aronowitz, S. 1988. Science as Power: Discourse and Ideology in Modern Society. Minneapolis, Minnesota: University of Minnesota Press.

Baudrillard, J. 1993. Simulacra and Simulations: Disneyland. In Social Theory: The Multicultural and Classic Readings, ed. C. Lemert, pp. 524-529. Boulder, Colorado: Westview Press.

Bennet, J., and George, S. 1987. The Hunger Machine: The Politics of Food. New York: Basil Blackwell.

Blaut, J. M. 1993. The Colonizer's Model of the World. New York: The Guilford Press.

Brown, L. R., Kane, H., and Ayres, E. 1993. Vital Signs 1993. New York: W. W. Norton.

Bull, D. 1982. A Growing Problem: Pesticides and the Third World Poor. Oxford, United Kingdom: Oxfam.

Busch, L., and Lacy, W. B. 1983. Science, Agriculture, and the Politics of Research. Boulder, Colorado: Westview Press.

Carney, J. 1993. Converting the Wetlands, Engendering the Environment: The Intersection of Gender with Agrarian Change in the Gambia. Economic Geography 69:329-348.

Central Bank, Sri Lanka. 1987. The Alleviation of Poverty in Sri Lanka. Colombo: Central Bank of Sri Lanka.

Chambers, R. 1983. Rural Development: Putting the Last First. New York: John Wiley.

Cloke, P., Philo, C., and Sadler, D. 1991. Approaching Human Geography: An Introduction to Contemporary Theoretical Debates. New York: The Guilford Press.

Cousins, M., and Hussain, A. 1984. Michel Foucault. New York: St. Martin's Press.

Demeritt, D. 1994. The Nature of Metaphors in Cul- tural Geography and Environmental History. Progress in Human Geography 18:163-185.

Derrida, J. 1978. Writing and Difference. Chicago: University of Chicago Press.

Dickson, D. 1988. The New Politics of Science. Chicago: The University of Chicago Press.

El-Ghonemy, M. R. 1990. The Political Economy of Rural Poverty: The Case for Land Reform. New York: Routledge.

Elkins, P., ed. 1986. The Living Economy: A New Economics in the Making. New York: Routledge.

Escobar, A. 1992. Imagining a Post-Development Era? Critical Thought, Development and Social Movement. Social Text 10:20-56.

1995. Encountering Development: The Making and Unmaking of the Third World. Princeton, New Jersey: Princeton University Press.

Esteva, G. 1992. Development. In The Development Dictionary: A Guide to Knowledge as Power, ed. W. Sachs, pp. 6-25. London: Zed Books.

Food and Agricultural Organization. 1987. Land Reform: Land Settlement and Rural Cooperatives. Rome: Food and Agricultural Organization of the United Nations.

. 1988. Land Reform: Land Settlement and Rural Cooperatives. Rome: Food and Agricultural Organization of the United Nations.

1990. Land Reform: Land Settlement and Rural Cooperatives. Rome: Food and Agricultural Organization of the United Nations.

Foucault, M. 1973a. Madness and Civilization. New York: Vintage Books.

1973b. The Order of Things: An Archaeology of the Human Sciences. New York: Vintage Books.

1975. The Birth of the Clinic. New York: Vintage Books.

1979. Discipline and Punish. New York: Vintage Books.

. 1980. POWER/KNOWLEDGE: Selected Interviews \& Other Writings. New York: Pantheon. . 1990. The History of Sexuality. New York: Vintage Books.

George, S. 1992. The Debt Boomerang. Boulder, Colorado: Westview Press.

Godlewska, A., and Smith, N., eds. 1994. Geography and Empire. Cambridge, Massachusetts: Basil Blackwell.

Goldman, R., and Papson, S. 1994. The Postmodernism that Failed. In Postmodernism and Social Inquiry, ed. D. R. Dickens and A. Fontana, pp. 224-253. New York: The Guilford Press.

Gottdiener, M. 1994. Semiotics and Postmodernism. In Postmodernism and Social Inquiry, ed. D. R. Dickens and A. Fontana, pp. 155-181. New York: The Guilford Press.

Graham, J. 1990. Theory and Essentialism in Marxist Geography. Antipode 22:53-66. 1992. Anti-essentialism and Overdetermina- 
tion: A Response to Dick Peet. Antipode 24:141156.

Gregory, D. J. 1978. Ideology, Science and Human Geography. London: Hutchinson.

Harrison, P. 1990. Inside the Third World. London: Penguin.

Harvey, D. 1989. The Condition of Postmodernity. Cambridge, Massachusetts: Basil Blackwell.

Hecht, S. B. 1985. Environment, Development and Politics: Capital Accumulation and the Livestock Sector in Eastern Amazonia. World Development 13:663-684.

Hecht, S. B., and Cockburn, A. 1990. The Fate of the Forest: Developers, Destroyers and Defenders of the Amazon. New York: Harper Collins.

Heilbroner, R. L., and Galbraith, J. K. 1987. The Economic Problem. Englewood Cliffs, New Jersey: Prentice-Hall.

Hewitt de Alcantara, C. 1976. Modernizing Mexican Agriculture: Socio-economic Implications of Technical Change, 1940-1970. Geneva, Switzerland: United Nations Research Institute for Social Development.

Hightower, J. 1973. Hard Tomatoes, Hard Times. Cambridge, Massachusetts: Schenkman.

Hunger. 1994. Transforming the Politics of Hunger. Washington, D.C.: Bread for the World Institute.

Illich, I. 1978. Towards a History of Needs. Berkeley, California: Heyday.

- 1992. Needs. In The Development Dictionary: A Guide to Knowledge as Power, ed. W. Sachs, pp. 88-101. London: Zed Books.

Jameson, F. 1984. Postmodernism; or, The Cultural Logic of Late Capitalism. New Left Review 146:53-92.

Jennings, B. H. 1988. Foundations of International Agricultural Research. Boulder, Colorado: Westview Press.

Kellner, D. 1991. Reading Images Critically: Toward a Postmodern Pedagogy. In Postmodernism, Feminism, and Cultural Politics, ed. H. A. Giroux, pp. 60-82. Albany, New York: State University of New York Press.

Kloppenburg, J. R. 1988. First the Seed: The Political Economy of Plant Biotechnology 1492-2000. New York: Cambridge University Press.

Lappe, F. M., and Collins, J. 1977. Food First: Beyond the Myth of Scarcity. New York: Ballantine Books.

Livingstone, D. N. 1992. The Geographical Tradition. Cambridge, Massachusetts: Basil Blackwell.

Lutz, M. A., and Lux, K. 1979. The Challenge of Humanistic Economics. Menlo Park, California: Benjamin/Cummings.

Lyotard, J. F. 1979. The Postmodern Condition: A Report on Knowledge. Minneapolis: University of Minnesota Press.

Marx, K. 1989 [1869]. A Contribution to a Critique of Political Economy. New York: International Publishers. Orig. published 1869.
Merchant, C. 1983. The Death of Nature: Women, Ecology and the Scientific Revolution. San Francisco, California: Harper \& Row.

Mooney, P. R. 1979. Seeds of the Earth. San Francisco, California: Institute for Food and Development Policy.

Nandy, A. 1992. State. In The Development Dictionary: $A$ Guide to Knowledge as Power, ed. W. Sachs, pp. 264-274. London: Zed Books.

Natter, W., and Jones, J. P. 1993. Signposts toward a Poststructuralist Geography. In Postmodern Contentious: Epochs, Politics, Space, ed. J. P. Jones, W. Natter and T. R. Schatzki, pp. 165-203. New York: The Guilford Press.

Natter, W., Schatzki, T. R., and Jones, J. P., eds. 1995. Objectivity and its Other. New York: The Guilford Press.

Oasa, E. K. 1987. The Political Economy of International Agricultural Research: A Review of CGIAR's Response to Criticisms of the "Green Revolution." In The Green Revolution Revisited: Critique and Alternatives, ed. B. Glaeser, pp. 1355. Boston: Allan \& Unwin.

Payer, C. 1991. Lent and Lost: Foreign Credit and Third World Development. London: Zed Books.

Peet, R. 1992. Some Critical Questions for Anti-essentialism. Antipode 24:113-130.

Peet, R., and Watts, M. 1993. Development Theory and Environment in an Age of Market Triumphalism. Economic Geography 69:227-253.

Pickles, J., and Watts, M. 1992. Paradigms for inquiry? In Geography's Inner Worlds, ed. R. F. Abler, M. G. Marcus, and J. M. Olson, pp. 301326. New Brunswick: Rutgers University Press.

Poster, M. 1990. Foucault, Marxism \& History. Cambridge, Massachusetts: Polity Press.

Proctor, R. N. 1991. Value-Free Science?: Purity and Power in Modern Knowledge. Cambridge, Massachusetts: Harvard University Press.

- 1995. Cancer Wars: How Politics Shapes What We Know \& Don't Know About Cancer. New York: Basic Books.

Rocheleau, D. 1991. Gender, Ecology, and the Science of Survival. Agriculture and Human Values 8:156-165.

Rogers, E. M. 1969. Modernization among Peasants: The Impact of Communication. New York: Holt, Rinehart and Winston.

Roseneau, P. M. 1992. Post-Modernisms and the Social Sciences. Princeton, New Jersey: Princeton University Press.

Rouse, J. 1987. Knowledge and Power: Toward a Political Philosophy of Science. Ithaca, New York: Cornell University Press.

Sachs, W., ed. 1992. The Development Dictionary: A Guide to Knowledge as Power. London: Zed Books.

Said, E. W. 1979. Orientalism. New York: Vintage Books. 
1993. Culture and Imperialism. New York: Alfred A. Knopf.

Sarup, M. 1988. An Introductory Guide to Poststructuralism and Postmodernism. New York: Harvester Wheatsheaf.

Sayer, A. 1992. Method in Social Science. New York: Routledge.

Shiva, V. 1991. The Violence of the Green Revolution: Third World Agriculture, Ecology and Politics. London: Zed Books.

Smith, N., and Godlewska, A. 1994. Critical Histories of Geography. In Geography and Empire, ed. A. Godlewska and N. Smith, pp. 1-8. Cambridge, Massachusetts: Basil Blackwell.

Timberlake, L. 1986. Africa in Crisis. London: Earthscan.

Trainer, T. 1994. Developed to Death. London: Green Print.

Ulluwishewa, R. 1992. Indigenous Knowledge Systems for Sustainable Development: The Case of Pest Control by Traditional Paddy Farmers in Sri Lanka. Journal of Sustainable Agriculture 3:51-62.

Van den Bosch, R. 1978. The Pesticide Conspiracy. Garden City, New York: Doubleday.

Warren, D. M. 1990. Indigenous Knowledge and Development. Washington, D.C.: The World Bank.

Watts, M. 1983a. Silent Violence: Food, Famine and Peasantry in Northern Nigeria. Berkeley, California: University of California Press.

- 1983b. Hazards and Crises: A Political Economy of Drought and Famine in Northern Nigeria. Antipode 15:24-34.

Waugh, P. 1992. Postmodernism. London: Edward Arnold.

WCED. 1987. Our Common Future: World Commission on Environment and Development. New York: Oxford University Press.
Wisner, B. 1988. Power and Need in Africa: Basic Human Needs and Development Policies. London: Earthscan.

Wolff, R. D., and Resnick, S. A. 1987. Economics: Marxian versus Neoclassical. Baltimore, Maryland: The John Hopkins University Press.

World Bank. 1974. Land Reform. Washington, D.C.: The World Bank Rural Development Series. . 1990. World Development Report 1990. New York: Oxford University Press. . 1992. World Development Report 1992. New York: Oxford University Press. . 1993a. World Development Report 1993. New York: Oxford University Press.

. 1993b. Implementing the World Bank's Strategy to Reduce Poverty. Washington, D.C.: The World Bank.

1993c. Poverty Reduction Handbook. Washington, D.C.: The World Bank.

Xenos, N. 1989. Scarcity and Modernity. New York: Routledge.

Yapa, L. 1993. What Are Improved Seeds? An Epistemology of the Green Revolution. Economic Geography 69:254-273.

- 1996. Innovation Diffusion and Paradigms of Development. In Concepts in Human Geography, ed. C. Earle, K. Mathewson, and M. Kenzer, pp. 231-270. Lanham, Maryland: Rowman \& Littlefield.

Yapa, L., and Wisner, B. 1995. Building a Case Against Economic Development. Geofournal 35:105-118.

Young, I. M. 1990. Justice and the Politics of Difference. Princeton, New Jersey: Princeton University Press.

Submitted 7/95; Accepted 2/96.

Yapa, Lakshman. 1996. What Causes Poverty?: A Postmodern View. Annals of the Association of American Geographers 86(4): 707-728. Abstract.

The dominant discourse on development presents poverty as an economic problem. It posits the existence of a poverty sector in the economy whose problems can be alleviated through economic growth, increased investment, creation of jobs, and higher income. We can call this the axiom of economic development. There are three major paradigms in the discourse on development: neoclassical economics, Marxism, and sustainable development. Despite profound differences in philosophy, they all regard development as the solution to the poverty problem. Contrary to that position, I have argued that conditions of deprivation experienced by poor people in the Third World are a form of socially constructed scarcity induced by the process of economic development. Scarcity experienced by the poor in the so-called poverty sector is manufactured outside this sector, within a nexus of relations-technical, social, ecological, cultural, political, and academic-diffused throughout the larger society. Each relation of the nexus constitutes a site at which scarcity is constructed through an interplay of discursive and nondiscursive practices. The dominant discourse on development poses an obstacle to the 
eradication of poverty because it contributes to the creation of scarcity and conceals how those mechanisms function, thereby disempowering the poor and misleading people of goodwill. Several themes from the writings of postmodern discourse theorists such as Lyotard and Foucault have helped in formulating these arguments. The following are some of the themes: development as a grand narrative, the subject/object binary in the conceptualization of a poverty sector, development and underdevelopment as a dividing practice, reductionism and the nexus of production relations, and a substantive view of poverty and power. Key Words: development, Foucault, nexus of production relations, postmodern discourse theory, poverty, socially constructed scarcity.

Correspondence: Department of Geography, 302 Walker Building, The Pennsylvania State University, University Park, Pennsylvania, 16802-5011. 